\title{
Analysis of molecular biology techniques for the diagnosis of human papillomavirus infection and cervical cancer prevention
}

\section{Análise de técnicas de biologia molecular para o diagnóstico de infecções causadas por papilomavírus humanos e a prevenção do câncer cervical}

\author{
Fernanda Nahoum Carestiato ${ }^{1}$, Kátia Cristina da Silva ${ }^{1}$, Daniela Signorelli Balthazar ${ }^{1}$, \\ Licínio Silva ${ }^{2}$, Marisa Marinho ${ }^{3}$, Ledy Horto dos Santos Oliveira ${ }^{1}$ \\ and Silvia Maria Baeta Cavalcanti ${ }^{1}$
}

\begin{abstract}
The objective of the present study was to evaluate the usefulness of molecular methodologies to access human papillomavirus genome in the genital tract. Samples from 136 women aged 17 to 52 years old obtained from the Dr. Sérgio Franco Laboratories between 2000 and 2001, were analyzed by the hybrid capture assay and amplified by PCR with generic primers MY09/MY11 and specific primers for types 16,18, 31,33, 35, 58. Viral genome was detected in $71.3 \%$ of the samples by hybrid capture and $75 \%$ by amplification. When cytopathology was used as a reference method for screening lesions, hybrid capture $(p=0)$ and amplification $(p=0.002)$ presented positive association. The 3 methods showed absolute agreement when cytopathology confirmed papillomavirus infection and high grade intraepithelial lesion. Disagreements occurred for 10 cases: seven inflammatory cases positive by PCR and negative for hybrid capture and 3 low squamous intraepithelial lesions positive for hybrid capture but negative for amplification. In conclusion, hybrid capture was shown to be sensitive and specific enough for use in clinical routines. Moreover, the evaluation of viral load values obtained by this method were shown to be related to the severity of the lesion and merit further studies to analyze the possible association with risk of progression to malignancy.
\end{abstract}

Key-words: Human papillomavirus. Squamous intraepithelial neoplasia. Cancer. Hybrid capture. Polymerase chain reaction.

\section{RESUM0}

O objetivo do nosso trabalho foi avaliar o emprego de métodos moleculares para comprovar a presença dos papilomavírus humanos no trato genital. Amostras de 136 pacientes com idades entre 17 e 52 anos, coletadas nos Laboratórios Dr. Sérgio Franco entre 2000 e 2001, foram analisadas pelas técnicas de captura híbrida e amplificação pela reação em cadeia da polimerase com primers genéricos MY09/MY11 e específicos para os tipos 16, 18, 31,33, 35, 58. 0 genoma viral foi detectado em 71,3\% dessas amostras pela captura híbrida e 75\% pela reação em cadeia da polimerase. Quando a citopatologia foi usada como método de referência para rastreamento das lesões, a captura $(p=0)$ e a amplificação $(p=0,002)$ demonstraram associação positiva. Os três testes demonstraram concordância absoluta quando a citopatologia diagnosticou processo compatível com papilomavírus ou lesão intraepitelial de alto grau. Dez casos discordantes ocorreram: sete casos de citologia inflamatório positivos na reação em cadeia da polimerase mas negativos na captura híbrida e 3 casos de lesão de baixo grau positivas na captura híbrida e negativas pela reação em cadeia da polimerase. Concluímos que a captura híbrida apresentou sensibilidade e especificidade adequadas para uso clínico. Avaliação da carga viral obtida por esta metodologia relacionou-se com a severidade da lesão e merece estudos adicionais a fim de determinar seu valor prognóstico para o câncer.

Palavras-chaves: Papilomavírus humanos. Neoplasia intraepitelial escamosa. Câncer. Captura do híbrido. Reação em cadeia da polimerase.

\footnotetext{
1. Laboratório de Diagnóstico Virológico do Departamento de Microbiologia e Parasitologia do Instituto Biomédico da Universidade Federal Fluminense, Niterói, RJ. 2. Departamento de Estatística da Faculdade de Matemática da Universidade Federal Fluminense, Niterói, RJ. 3. Setor de Biologia Molecular do Laboratório Sérgio Franco, Rio de Janeiro, RJ.

Trabalho realizado no Laboratório de Diagnóstico Virológico, Instituto Biomédico da Universidade Federal Fluminense e financiado pelo CNPq. Address to: Dra. Silvia M.B. Cavalcanti. Lab. Virologia/Depto Microbiologia e Parasitologia/IB/UFF. Rua Ernani Melo 101, Centro, 24210-030 Niterói, RJ. Tel: 5521 2629-2431; Fax: 5521 2629-2413

e-mail: silviacavalcanti@vm.uff.br

Recebido para publicação em 22/11/2005

Aceito em 10/8/2006
} 
Human papillomavirus (HPV) infection is the major cause of most cervical cancer and cervical intraepithelial neoplasia (CIN) worldwide ${ }^{17}$. Nearly 500,000 cases of cervical cancer arise each year and 200,000 women eventually die of the disease. In Brazil, uterine cancer is the third cause of death due to neoplasia ${ }^{14}$. Consequently, there is strong motivation to evaluate the use of HPV testing in cervical cancer screening, which requires further improvements in the standardization of testing methods. HPV detection has generally been conducted by hybridization and polymerase chain reaction (PCR) methods. However, neither research assays nor commercial kits ( dot blot or in situ hybridization) have been shown to be adequate for clinical use. An assay for routine clinical use requires reliable and accurate detection of the broad range of pathogenic HPV types infecting the genital tract?.

Diagnosis of cervical disease, indicating the presence of abnormal cervical epithelial cells, is usually obtained by microscopic examination of Papanicolaou stained smears. This has been the method of choice since the 1950's, proving valuable for mass screening and enabling detection of lesions early enough to be treated effectively. The Pap smear, however, has limited sensitivity in detecting cancer precursors, giving a false-negative rate ranging from 20 to $30 \%{ }^{8}$. Hence, complementary methods that may enable the improvement of cervical disease diagnosis have been studied for the past two decades. Recently developed, the second generation of the hybrid capture assay ( HCA II) for HPVDNA detection from Digene Diagnostics ( Silver Spring, Md), is a nonradioactive, relatively rapid, liquid hybridization assay designed to detect eighteen HPV types divided into high-risk and low-risk groups. A possible unique advantage compared with other available HPV test kits, the hybrid capture test is also designed to provide quantitative estimates of viral load, which may correlate with the grade and natural history of cervical pathology ${ }^{22}$.

Given the fact that diverse clinical laboratories are currently using this method, the present investigation was conducted to compare HCA II with PCR, aimed at providing tools for the interpretation of this new available procedure, with the objective of contributing to cancer prevention.

\section{MATERIAL AND METHODS}

Study population and collection of specimen. The study was approved by the Ethical Committee of the Fluminense Federal University (21/2000). The population included 136 women attended at the Sérgio Franco Laboratories, Rio de Janeiro, Brazil, from January 2000 to December, 2001. Women were referred to hybrid capture after clinical suspicion of HPV infection during a routine exam. The cervical smears were collected using a cervical cytobrush and transported in specimen transport medium ( Digene Diag, Md) .

Cytologic test. The Papanicolaou test was developed and smears were classified as normal for normal epithelium, inflammatory for minor alterations of cervical cells, ASCUS for alterations of squamous cells of undetermined significance, HPV for alterations suggestive of HPV infection, LSIL for low-grade squamous intraepithelial lesions, HSIL for high-grade squamous intraepithelial lesions in situ carcinoma and SCC for squamous cell carcinoma.

Human papillomavirus testing by hybrid capture. The assay kit detects low and high-risk HPV genomes combined in two cocktails: group A containing the low-risk group detects the types more commonly associated with condyloma acuminatum: HPV types 6, 11, 42, 43 and 44 and group B containing the high-risk types 16, 18, 31, 33, 35, 39, 45, 51, $52,56,58,59$ and 68 . According to the kit protocol, specimens were treated with sodium hydroxide to hydrolyze the RNA specimen and denature the DNA. The liberated single strand DNA was hybridized in solution with a RNA probe mix consisting of the high-risk or the low-risk HPV types. Each reaction mixture, containing any number of RNA-DNA hybrids that formed, was transferred to a capture tube coated with antibodies to the hybrids; consequently, immobilizing them. Bound RNA-DNA hybrids were then reacted with an alkaline phosphatase-conjugated antibody directed against the hybrids. Nonreactive material was removed by washing, and a dioxetanebased chemiluminescent compound, Lumi-Phos 530, was added as a substrate for alkaline phosphatase. The light produced by the ensuing reaction was measured by a Luminometer. Light measurements were expressed as relative light units (RLU). As a negative control, sonicated herring sperm DNA in Digene transporting medium $(100 \mu \mathrm{g} / \mathrm{ml})$ was used. Triplicate specimens of HPV 16 or HPV11 DNA at 10pg/ml served as the positive controls for high-risk and low-risk probes, respectively. All RLU measurements for specimens were divided by the mean RLU of the three appropriate positive controls ( PCs) to give a ratio of specimen RLU/PC. A ratio of 1.0 or greater was regarded as positive for HPV DNA, and a ratio of less than 1.0 was regarded as negative. Since the amount of light produced by the hybrid capture assay is theoretically proportional to the amount of target HPV DNA, HCA II can be analyzed as a quantitative method ${ }^{8}$.

Human papillomavirus testing by polymerase chain reaction. The PCR assay was realized from the clinical samples initially collected for HCA II. The specimens were stored at $-20^{\circ} \mathrm{C}$ in sodic acidum until required. First, the specimens were neutralized using $1 \mathrm{~N} \mathrm{HCl}$. DNA extraction was performed as follows: $500 \mathrm{pl}$ of the neutralized specimen were precipitated on $50 \mu \mathrm{l}$ of the sodium acetate and 1,250 $\mu \mathrm{l}$ of $100 \%$ ethanol. The specimens were incubated at $-20^{\circ} \mathrm{C}$ overnight. The following day, these samples were centrifuged for $30 \mathrm{~min}$ at 14,000 rpm. After centrifugation, the supernatant was discarded and the remaining precipitated sample was washed in $70 \%$ ethanol and centrifuged for $10 \mathrm{~min}$ at $14,000 \mathrm{rpm}$. The precipitate was left to dry atroom temperature and resuspended in $50 \mathrm{\mu l}$ of distilled water and stored at $-20^{\circ} \mathrm{C}$.

Polymerase chain reaction amplification of generic human papillomavirus. Consensus primers MY09/MY11, which amplify 450 base pair (bp) DNA sequences within the L1 region of HPV, were used to detect generic HPVDNA. Amplification was carried out in 50 $\mu$ l reaction mixture (1X PCR buffer, 
$200 \mu \mathrm{M}$ dNTPs, $1.5 \mathrm{mM} \mathrm{MgCl}$, 50pmol of each primer, $0.25 \mathrm{U}$ unit of Taq polymerase, and $5 \mu \mathrm{l}$ of sample) with 35 cycles of amplification. Each cycle included a denaturation step at $94^{\circ} \mathrm{C}$ for 1 minute, an annealing step at $55^{\circ} \mathrm{C}$ for 2 minutes, and a chain elongation step at $72^{\circ} \mathrm{C}$ for 2 minutes using a DNA thermal cycler (Perkin Elmer, CETUS). The actin primers $(0.1 \mathrm{pmol}$ each), which amplify a 360bp region of the human DNA, were used as an internal control. PCR products were analyzed on 1.3\% agarose gel with ethidium bromide staining for visualization of DNA under ultraviolet light and their PM determined by comparison with a 100bp DNA ladder.

Polymerase chain reaction amplification for human papillomavirus using specific human papillomavirus primers. HPV typing was performed by PCR using primers from the E6 gene DNA sequences of HPV 16, 18, 31, 33, 35 and $58^{18}$. These primers yielded 230, 89, 134, 119, 97, 132, 186, and 100-bp fragments, respectively. The PCR included 25 cycles as described: $94^{\circ} \mathrm{C}$ for 30 seconds, $60^{\circ} \mathrm{C}$ for 1 minute, and $72^{\circ} \mathrm{C}$ for 1 minute. The PCR run was completed by extension for 10 minutes at $72^{\circ} \mathrm{C}$. Negative controls for background were included. The primers Ac1 and Ac2, specific for the amplification of a 330 bp fragment of the actin gene, were used as a control of DNA extraction. Positive controls included SiHa and HeLa cell cultures presenting HPV 16 and 18 genomes, respectively.

Statistical analysis. The statistical significance of the results was analyzed using the SPSS- 8 computer program (2002-USA). Comparisons between PCR and HCA were realized by the McNemar test $(p<0.05)$. Association indexes were obtained by the Fisher exact test. Viral load measurements were evaluated by the Kruskall-Wallis test $(p<0.05)$.

\section{RESULTS}

The present study compared the results realized by PCR and hybrid capture HCA II tests for diagnosing cervical infection by HPV in 136 samples of cervical smears. The mean age of the patients was 30.6 ranging from 17 to 52 years old. The prevalent interval for HPV infection was from 21-30 years old. Samples were classified according to the Bethesda system into inflammatory (41/136), ASCUS (11/136), HPV (26/136), LSIL (55/136) and HSIL (3/136). A statistically significant upward trend in age from inflammatory cases (medium age $=26.9)$, ASCUS, HPV and LSIL ( medium age $=28.3$ ) and HSIL ( medium age $=39.5)(p<0.0001)$ was clearly observed.

Table 1 shows the results obtained by HCA II: of the 136 samples studied, 97 (71.3\%) were infected by HPV. High-risk group B was the most prevalent group detected by HCA II, accounting for 51 cases alone or mixed with group A in 34 cases. Hence, 85 (62.5\%) women out of the 136 studied showed high-risk infections.

Table 2 presents the PCR results: of the 136 samples studied, 102 (75\%) women were HPV-positive: 38 (37.3\%) were HPV 16; 22 (21.6\%) HPV 18; 5 (4.9\%) HPV 33; 5 (4.9\%) HPV 35; and 5 (4.9\%) HPV 58. Twenty seven (26.5\%) cases ( HPV X) remained untyped by PCR.
Table 1 - Detection of low and high-risk HPV obtained by the hybrid capture assay according to colpocytology.

\begin{tabular}{lcccccccc}
\hline & \multicolumn{3}{c}{ Hybrid capture } & & \multicolumn{2}{c}{ Prevalence } \\
\cline { 2 - 4 } Colpocytology & Number of & Low-risk & High-risk & Multiple & & $n^{0}$ & $\%$ \\
diagnosis & patients & HPV & HPV & infection & & \\
\hline Inflammatory & 41 & 2 & 10 & 5 & & $17 / 41$ & 41.4 \\
ASCUS & 11 & - & 2 & - & & $2 / 11$ & 18.2 \\
HPV & 26 & 7 & 9 & 7 & & $23 / 26$ & 88.5 \\
LSIL & 55 & 3 & 27 & & 22 & & $52 / 55$ & 94.5 \\
HSIL & 3 & - & 3 & - & & $3 / 3$ & 100.0 \\
\hline Total & 136 & 12 & 51 & 34 & & $97 / 136$ & 71.3
\end{tabular}

ASCUS: atypical squamous cell of undetermined significance; LSIL: low grade squamous intraepithelial lesions; HSIL: high grade squamous intraepithelial lesions. HPV: human papillomavirus.

Table 2 - Human papillomavirus types detected by the polymerase chain reaction according to the colpocytological diagnosis.

\begin{tabular}{lcrrrrrrr}
\hline Colpocytology & Number of & \multicolumn{7}{c}{ HPV types in PCR } \\
\cline { 3 - 9 } diagnosis & patients & MY & 16 & 18 & 33 & 35 & 58 & HPVX \\
\hline Inflammatory & 41 & 24 & 10 & 2 & 2 & - & - & 10 \\
ASCUS & 11 & 3 & 2 & - & - & - & - & 1 \\
HPV & 26 & 23 & 8 & 6 & - & 1 & - & 8 \\
LSIL & 55 & 49 & 16 & 13 & 3 & 4 & 5 & 8 \\
HSIL & 3 & 3 & 2 & 1 & - & - & - & - \\
\hline Total & 136 & 102 & 38 & 22 & 5 & 5 & 5 & 27
\end{tabular}

No HPV 31 was detected. X = untyped. ASCUS: atypical squamous cell of undetermined significance; LSIL: low grade squamous intraepithelial lesions; HSIL high grade squamous intraepithelial lesions. HPV: human papillomavirus.

Table 3 presents the results obtained by both HCA II and PCR: concordant results were observed for 132 (97.1\%) samples while disagreements were found for $11(2.9 \%)$ samples: 7 inflammatory cases negative for HCA but positive for PCR, 1 case of ASCUS positive for PCR and negative for HCA II and 3 cases of LSIL positive for HCA II, but negative for PCR. The two tests presented a good association index according to the Fisher exact test ( $p=0.0002$, Fisher Test) and a kappa coefficient of $k=0.76$ ( $95 \%$ confidence interval), indicating an excellent agreement index for diagnosing HPV infection. The prevalence of high and low-risk types of HPV by the hybrid capture assay in comparison with the results of PCR is presented in the Table 4. Sensibility was higher for HCA II (99.2\%) than PCR (97.1\%) but specificity rate was lower for both techniques (HCA - 86\% and PCR - 85.2\%).

The mean viral load values measured by the hybrid capture assay are shown in Table 4. An increase in the values occurred, according to the severity of the cytologic test for both

Table 3 - Results and agreement rates obtained by PCR and hybrid capture according to colpocytology.

\begin{tabular}{lcccc}
\hline $\begin{array}{l}\text { Colpocytology } \\
\text { diagnosis }\end{array}$ & $\begin{array}{c}\text { Number of } \\
\text { patients }\end{array}$ & $\begin{array}{c}\text { Hybrid } \\
\text { capture }\end{array}$ & PCR & $\begin{array}{c}\text { Agreement } \\
\%\end{array}$ \\
\hline Inflammatory & 41 & 17 & 24 & 82.9 \\
ASCUS & 11 & 2 & 3 & 90.9 \\
HPV & 26 & 23 & 23 & 100.0 \\
LSIL & 55 & 52 & 49 & 94.5 \\
HSIL & 3 & 3 & 3 & 100.0 \\
Total & 136 & 97 & 102 & 91.9 \\
\hline
\end{tabular}

Disagreements: 1 ASCUS, 3 LSIL. ASCUS: atypical squamous cell of undetermined significance; LSIL; low grade squamous intraepithelial lesions; HSIL; high grade squamous intraepithelial lesions. HPV: human papillomavirus. 
Table 4 - Mean viral load values (RLU/PC) measured by hybrid capture and its relation to the cytological diagnosis and to the HPV group.

\begin{tabular}{lccccr}
\hline HPV Group & \multicolumn{5}{c}{ Cytological diagnosis } \\
\cline { 2 - 6 } by HCA & Inflammatory & ASCUS & HPV & LSIL & HSIL \\
\hline Group A & 21.9 & 312 & 406.3 & 585.0 & - \\
Group B & 195.5 & 234.4 & 363.4 & 767.4 & 923.1 \\
\hline
\end{tabular}

Group A - low risk types; Group B - high risk types.

benign ( Group A: inflammatory $=2,119$ to LSIL $=585$ ) and oncogenic HPV (Group B: inflammatory: 195.5 to HSIL: 923.1). The Kruskal-Wallis $(p=0.05)$ test showed that there was an upward trend of RLU measurements associated with increased lesion severity for both the low-risk (group A) and high-risk (group B) HPV groups. Viral load values proved to be statistically different between inflammatory and LSIL/HSIL cases.

\section{DISCUSSION}

The initial impact after the adoption of Papanicolaou screening test in Mass Programs for Cancer Prevention was astonishing, determining a 70\% reduction in mortality indexes worldwide. Nevertheless, atter ten years, indexes stabilized and even increased due to a significant group of women failing to regularly participate in such programs. In the last decade, HPV has presented earlier in the female genital tractand the prevalence of infection has increased, making this virus the agent of the most prevalent sexually transmitted viral disease in several countries $^{10}$. Moreover, the Papanicolaou test presents intrinsic rates of false-positives and false-negatives, reinforcing the need to use complementary tests when screening for HPV infection. Molecular biology methodologies, such as PCR, have proved their usefulness in detecting HPV infection, thus contributing to the early diagnosis of women at risk for cervical cancer ${ }^{16}$. Nevertheless, these techniques are expensive, laborious and frequently reveal cervical HPV infections that are only transient?

More recently, hybrid capture assay is currently in use for testing HPV DNA in Brazil and worldwide, however, no studies have been conducted to test its usefulness in this country. It is not as laborious as PCR, but is still very expensive and its clinical relevance remains controversial. IARC have proposed that to reduce costs and optimize HCA use in routine diagnosis, the focus should be on women over 35 years old, usually presenting persistent infections or the detection of ASCUS in cytology, due to their increased risk for malignant transformation ${ }^{5}$.

The present investigation was conducted to compare HCA II with PCR, with the aim of providing tools for the interpretation of the usefulness of this newly available procedure in Brazil. For that purpose, cervical samples were studied by both HCA II and PCR assays. The tests were concordant for 132 (97.1\%) out of 136 samples. HCA II detected HPV infection in 71.3\% (97/136) of patients, while PCR detected HPV DNA in 75\% (102/136). Discrepancies in the results were observed: seven cases of inflammatory cytology presented HPV by PCR. Perhaps these results are due to the greater sensibility of PCR, revealing latent infections, but when analyzed using cytology parameters, they could represent false-positives, since there were no apparent lesions ${ }^{5}$. Nevertheless, women presenting high-risk HPV, especially over 35 years old, must be followed-up cautiously, since they may be at a higher risk of developing SILs, as previously proposed by Koutsky ${ }^{13}$.

It should be noted that the prevalence described herein is very high, though the current study was not designed to be a prevalence study of the general population. Samples from women referred for further exams after clinical suspicion were analyzed. Hence, high prevalence was already expected. Of some importance is the fact that PCR failed to detect three samples classified as LSIL by cytology and positive for highrisk types of HPV in HCA II. Muñoz ${ }^{18}$ previously described false negatives when using MY primers for screening HPV infection and suggested the use of an additional pair of primers (GP5/6) to reduce these events. We suggest that screening by MY primers is still useful, but samples might also be tested for high-risk HPV, especially HPV 16 and 18, the two most oncogenic and prevalent types detected in Rio de Janeiro, Brazil ${ }^{19}$. The other discrepancy was observed for an ASCUS sample: HCA II was positive, while PCR proved negative. ASCUS diagnosis is exclusion for HPV infection and the HPV infection here described might represent a falsepositive by HCA II. Previous studies have already suggested false positives and the authors associated the cases to low viral loads measured by HCA, suggesting that they could be solved by changing the reaction cut off from 1.0 to $3.0 \mathrm{RLU} /$ $\mathrm{PC}^{15}{ }^{16}$. In fact, this PCR(-) ASCUS case was positive for HCA II, showing a viral load of 2.09 RLU. Nevertheless, the diagnosis of ASCUS continues to present problems and the definition of criteria is still under study, since misdiagnosis is often seen and an observation of ASCUS might even represent HSIL ${ }^{21}$. Manos et $\mathrm{a}^{15}$ has already proposed that ASCUS diagnosis would indicate testing for HPV DNA, as well as a colposcopy exam, in order to discard the possibility of a lost high-grade lesion.

In this study, statistical parameters of sensibility and specificity for HCA II and PCR were described, using the cytopathological test as a reference method of screening Brazilian patients. Sensibility rates of $99.2 \%$ for HCA and $97.1 \%$ for PCR were obtained, while specificity rates were a little lower for both techniques ( $86 \%$ and $85.2 \%$ for HCA and PCR, respectively). Kappa values revealed a good association index $(k=0.76)$. These results are similar to those described by Illescas et $\mathrm{al}^{12}$ and show that both PCR and HCA II are excellent tests for screening patients infected by HPV and that might be at a greater risk of cancer.

High prevalence rates of oncogenic HPV infections were demonstrated and accounted for 85/95 cases by HCA and 75/ 95 cases by PCR. Twenty-seven HPV X were found that could represent types not tested in the PCR used here. HCA showed 12 low-risk HPV, consequently, these 12 low-risk cases plus a further 15 low or high-risk HPV types were not determined by PCR. On the other hand, it could be argued that these are high risk types due to the high prevalence of these types by HCA. Poljak ${ }^{20}$ suggested that they could represent falsepositive results obtained by cross hybridization with low-risk 
or nonrepresented types in Cocktail B. The possibility of equivocal identification of HPV resulting from cross hybridization is currently being resolved by third generation kit HCA III ${ }^{21}$, since erroneous diagnosis of a high-risk HPV has relevant consequences for patients, leading to errors in clinical conduct and causing unnecessary personal stress ${ }^{22}$.

In Table 4, data points to a statistically significant increase in the viral load measurements according to the severity of the lesions. The usefulness of measuring viral load by HCA II has been the object of several studies. Clavel et a ${ }^{23}$ found no significant relation between measurements and lesions, but, Castle et $\mathrm{a}^{21}$ found an strict relation between high viral load and SIL lesions. Further studies are required to amplify current knowledge and help in elucidating the meaning of HCA viral load with regard to the disease.

In the present work, the age interval of greatest prevalence was 20-30, coincident with the mean age of the participants and with the peak of sexual activity. Most of the infections are transitory in these periods and, in fact, prevalence decreased markedly after 35 years of age. Several authors have suggested that above 35 years of age, infections might indicate viral persistence, probably caused by oncogenic HPV and thus represent a greater risk of cancer for the affected women ${ }^{41}$.

In spite of being an easily preventable and treatable disease, cervical cancer is still presenting high rates of morbidity and mortality among Brazilian women. Molecular techniques capable of detecting HPV infection are expensive and can not be used in routine diagnosis, however, these would complement cervical screening, when applied subsequent to the Pap test, in order to reduce the risk of oncogenesis. In this study, a high prevalence rate of oncogenic infection was found, mainly HPV 16. Severity of the studied lesions seemed to be associated with high viral loads obtained by HCA. Both techniques showed good agreement and revealed oncogenic infections in patients over 35 years of age, associated with HPV persistence in the cervix. Thus, these patients, as well as those presenting progressive or recurrent lesions, should be tested for high risk HPV infection, since these represent an increased risk for oncogenesis.

\section{REFERENCES}

1. Castle PE, Lorincz AT, Lohnas IM, Scott DR, Glass AG, Sherman ME, Schussler JE, Schiffman M. Results of human papillomavirus DNA testing with the hybrid capture II assay are reproducible. Journal of Clinical Microbiology 40: 1088-1090, 2002.

2. Castle PE, Schiffman M, Weeler CM. Hybrid capture 2 viral load and the 2year cumulative risk of cervical intraepithelial neoplasia grade 3 or cancer. American Journal of Obstetrics and Gynecology 191: 1590-1597, 2004.

3. Cavalcanti SMB, Zardo LG, Passos MRL Oliveira LHS. Epidemiological aspects of Human papillomavirus infection and cervical cancer in Brazil. Journal of Infection 40: 80-87, 2000.

4. Clavel C, Masure M, Bory JP, Putaud I, Mangeonjean C, Lorenzato M, Nazeyrollas P, Gabriel R, Quereux C, Birembaut P. Human papillomavirus testing in primary screening for the detection of cervical lesions: a study of 7932 women. British Journal of Cancer 84: 1616-1623, 2001.

5. Cope JU, Hildesheim A, Schiffman MH, Manos MM, Lorincz AT, Burk RD, Glass AG, Greer C, Scott DR, Sherman M, Kurman RJ, Liaw KL. Comparison of th hybrid capture test and PCR for the detection of HPV DNA in Cervical specimens. Journal of Clinical Microbiology 35: 2262-2265, 1997.

6. Cox JT, Lorincz AT, Schiffman MH. Human papillomavirus testing by hybrid capture appears to be useful in triaging women with a cytologic diagnosis of ASCUS. American Journal of Obstetrics and Gynecology 172: 946-954, 1995.

7. Dillner J. Trends over time in the incidence of cervical neoplasia in comparison to trends over time in human papillomavirus infection. Journal of Clinical Virology 47: 649-652, 2000.

8. Farthing A, Masterson P, Mason WP, Vousden KH Human papillomavirus detection by hybrid capture and its possible clinical use. Journal of Clinical Pathology 47: 649-652, 1994.

9. Ferenczy A. Viral testing for genital papillomavirus infection. International Journal of Gynecological Cancer 5: 321-328, 1995.

10. Gilbert SM. Extensive Condylomata Acuminata: Medical and Surgical Management. Journal of Urology 16: 65-76, 2003.

11. Iftner T, Villa L. Human papillomavirus technologies. Chapter 12. Journal of the National Cancer Institute Monographs 31: 80-88, 2003.

12. Illescas L. Captura Híbrida: Actualización. Gineconet, SA. http:// www. gineconet.com, 2001.

13. Koutsky LA, Holmes KK, Critchlow CW, Stevens CE, Paavonen J, Beckman AM, DeRouen TA, Galloway DA, Vernon D, Kiviat NB. A cohort study of the risk of cervical intraepithelial neoplasia grade 2 and 3 in relation to papillomavirus infection. New England Journal of Medicine 327:1272-1278, 1992.

14. Lopes ER, Rebelo, MS, Abreu E, Silva, VLC, Eisenberg ALA, Lavor MF. Comportamento da população brasileira feminina em relação ao câncer cérvico-uterino. Jornal Brasileiro de Ginecologia 105: 505-515, 1995.

15. Manos MM, Kinney WK, Hurley LB. Identifying women with cervical neoplasia using human papillomavirus testing for equivocal Papanicolaou results. Journal of American Medical Association 281: 1605-1610, 1999.

16. Molijn A, Kleter B, Quint W, van Doorn LJ. Molecular dignosis of Human papillomavirus infections. Journal of Clinical Virology, 325: S43-S51, 2005.

17. Muñoz N. Human papillomavirus infection and cancer: the epidemiological evidence. Jornal of Clinical Virology 19: 1-5, 2000.

18. Muñoz N, Bosch X, Sanjos, S, Herrero R, Castellsague X, Shahk V, Snijders PJF, Mujer CJLM. Epidemiologic classification of human papillomavirus types associated with cervical cancer. The New England Journal of Medicine 348: 518-527, 2003.

19. Oliveira LHS, Rodrigues EVM, Pantaleão JA, Lopes APTAS, Cavalcanti SMB. Human papillomavirus and co-factors to cervical cancer among women attended at University Hospital of Universidade Federal Fluminense. Jornal Brasileiro de Doenças Sexualmente Transmissíveis 14: 23-27, 2002.

20. Poljak M, Marin IJ, Seme K, Vince A. Hybrid capture II HPV Test detects at least 15 human papillomavirus genotypes not included in its current highrisk probe cocktail. Journal of Clinical Microbiology 25: S89-S97, 2002.

21. Smith AE, Sherman ME, Scott DR, Tabbara SO, Dworkin L, Olson J, Thompson J, Faser C, Snell J, Schiffman M. Review of the Bethesda Syistem Atlas does not improve reproducibility or accuracy in the classification of atypical squamous cells of undetermined significance smears. Cancer Cytopathology 90: 201-206, 2000.

22. Sun CA, Liu JF, Wu DM, Nieh S, Yu CP, Chu TY. Viral load of high risk human papillomavirus in cervical squamous intraepithelial lesions. International Journal Gynecology and Obstetrics 76: 41-47, 2002.

23. Terry G, Ho L, Londesborough P, Cusick J, Lohnas IM, Lorincz. Detection of high-risk HPV types by the hybrid capture 2 test. Journal of Medical Virology 65: 155-162, 2001. 